\title{
A Three-dimensional Mathematical Modelling of Drainage Behavior in Blast Furnace Hearth
}

\author{
Koki NISHIOKA, Takayuki MAEDA and Masakata SHIMIZU \\ Department of Materials Science and Engineering, Faculty of Engineering, Kyushu University, 6-10-1, Hakozaki, Higashi-ku,
} Fukuoka 812-8581 Japan.

(Received on December 16, 2004; accepted on February 22, 2005)

\begin{abstract}
Stable blast furnace operation is required to reduce energy consumption in iron and steelmaking industry. For the stable blast furnace operation, precise controlled drainage is one of the important factors. However, the effects of the various in-furnace conditions on the stable operation were not examined well. Therefore, in this work, basic characteristic features of drainage in a blast furnace hearth were examined.

Two- and three-dimensional mathematical model were developed based on the finite difference method to simulate molten iron and slag flow in a hearth of a blast furnace. Pressure drop evaluation model in a taphole was developed to reflect pressure variation in a blast furnace hearth on drainage rate of molten iron and slag for the three-dimensional mathematical model.

The two-dimensional mathematical model results were validated with measured interfaces shapes obtained using an experimental model. The three-dimensional mathematical model results were validated with measured total, iron and slag drainage rate of Chiba No. 6 blast furnace. The results indicate that the drainage behavior and residual iron and slag volume were affected by the conditions in the hearth. The taphole conditions dominate the total drainage rate under the term of assumed blast furnace conditions. In order to reduce the residual slag volume, the taphole diameter change during the tap should be controlled. The decrease of the coke diameter causes increase of the residual slag volume, decrease of the residual iron volume.
\end{abstract}

KEY WORDS: iron and slag flow; residual slag volume; numerical simulation; VOF method; blast furnace hearth; ironmaking.

\section{Introduction}

Increasing blast furnace volumes and production rates cause an increase in taphole load due to an increase in drainage rate. In these situations, high levels of residual slag volume in the blast furnace hearth become one of the most significant issues for the blast furnace operation. ${ }^{1-4)}$

To maintain the blast furnace hearth in good condition, it is necessary to clarify the drainage behavior of molten iron and slag in the hearth. Especially, the slag flow behavior should be understood precisely. ${ }^{1-7)}$

Fukutake and Okabe proposed 'flow out coefficient', $F_{\mathrm{L}}$, and they concluded that their correlation can be used to estimate residual slag volume in a blast furnace. ${ }^{1-3)}$ At the same time, the effect of the iron phase below the taphole was not considered. Tanzil et al. revealed that it is possible to drain the iron phase considerably below the taphole under the conditions of two-liquids system, ${ }^{4)}$ however, the effects of the various in-furnace conditions on the residual volume of the molten iron and slag were not examined well. Nouchi et al. examined the effect of particle free space on hearth drainage efficiency by using immiscible two different density fluids. ${ }^{6}$ They reported the coke free zone in front of the taphole drastically changed the residual slag volume in the hearth. However, the effect of other in-fur- nace conditions for examples, slag viscosity, iron and slag density has not been examined because immiscible appropriate liquids for their experiment are limited.

Therefore, in this work, two- and three-dimensional unsteady state mathematical model were developed based on the finite difference method to simulate molten iron and slag flows in a hearth of a blast furnace. Surface shapes of the molten iron and slag in the blast furnace hearth were estimated with three-dimensional mathematical models. The effects of coke diameter of packed bed on the residual iron and slag volume, and the drainage rate of the iron and slag were investigated.

\section{Two-dimensional Modelling}

Gas-slag and slag-iron interfaces in a blast furnace hearth should be identified exactly to describe the iron and slag drainage behavior. However, reliable detecting methods of the interfaces shapes in commercial blast furnaces have not been established. On the other hand, three-dimensional physical model only gives cross-sectional information for the validation of mathematical model concerning the interfaces shapes. Therefore, two-dimensional mathematical and physical model were developed to confirm that the VOF method ${ }^{8)}$ can describe drainage behavior and inter- 
faces shapes of immiscible fluids having different properties.

\subsection{Two-dimensional Mathematical Modelling}

The governing equations for fluid flow used in the twodimensional mathematical model are based on the HSMAC method, ${ }^{8)}$ are described by Eqs. (1)-(3).

$$
\begin{aligned}
& \frac{\partial u}{\partial x}+\frac{\partial v}{\partial y}=0 \\
& \frac{\partial \rho u}{\partial t}+u \frac{\partial \rho u}{\partial x}+v \frac{\partial \rho u}{\partial y} \\
& =-\frac{\partial p}{\partial x}+\frac{\partial}{\partial x}\left(\mu \frac{\partial u}{\partial x}\right)+\frac{\partial}{\partial y}\left(\mu \frac{\partial u}{\partial y}\right)+\rho S_{u} \\
& \frac{\partial \rho v}{\partial t}+u \frac{\partial \rho v}{\partial x}+v \frac{\partial \rho v}{\partial y} \\
& =-\frac{\partial p}{\partial y}+\frac{\partial}{\partial x}\left(\mu \frac{\partial v}{\partial x}\right)+\frac{\partial}{\partial y}\left(\mu \frac{\partial v}{\partial y}\right)+\rho S_{v}-\rho g
\end{aligned}
$$

where $u$ is the horizontal velocity $(\mathrm{m} / \mathrm{s}), v$ is vertical velocity $(\mathrm{m} / \mathrm{s}), x$ and $y$ are coordinates $(\mathrm{m}), t$ is time $(\mathrm{s}), \rho$ is density of fluids $\left(\mathrm{kg} / \mathrm{m}^{3}\right), p$ is pressure of fluids $(\mathrm{Pa}), \mu$ is viscosity $(\mathrm{Pa} \cdot \mathrm{s}), g$ is acceleration due to gravity $\left(\mathrm{m} / \mathrm{s}^{2}\right)$, and $S$ is an interaction force between fluid and 2 flat parallel plates $\left(\mathrm{m} / \mathrm{s}^{2}\right)$. In the two-dimensional mathematical model, gas, slag and iron were treated as one fluid having local properties, which correspond to each phase.

\subsection{Representation of Interfaces}

For the determination of the fluid properties in each computational cell, it is necessary to compute the proportion of gas, iron and slag in each cell. Therefore, gas-slag and slag-iron interfaces should be identified exactly. To distinguish the interfaces, the VOF method ${ }^{9)}$ was applied for the calculation of interfaces (gas-slag, slag-iron). Generally, the VOF method is used to track free boundaries in two- or three-dimensional meshes. Although, in this work, VOF is also used to identify slag-iron interface, as shown in Fig. 1. A unit value of $\mathrm{VOF}_{1}$ would correspond to a cell full of liquid. A unit value of $\mathrm{VOF}_{2}$ would correspond to a cell full of iron. Cells with $\mathrm{VOF}_{2}$ values between zero and unit value must then contain an iron-slag surface. The slag-iron ratio of each cell was calculated from $\mathrm{VOF}_{1}$ and $\mathrm{VOF}_{2}$. Properties of each cell were determined by weighted average of the fluid (gas-slag, slag-iron) existed in the cell. The donor-accepter method ${ }^{9)}$ was used to solve the VOFs.

\subsection{Two-dimensional Physical Modelling}

A schematic view of the experimental equipment for the validation of the two-dimensional mathematical model is shown in Fig. 2. The experimental equipment was designed based on Tanzil et al.'s work. ${ }^{4)}$ The vessel was built with 2 acrylic plastic plates of $875 \mathrm{~mm}$ in width, $440 \mathrm{~mm}$ in height and $10 \mathrm{~mm}$ in depth. There are 3 tapholes on each side of the vessel. The diameter of the tapholes is $6 \mathrm{~mm}$. The tapholes were connected to liquid receivers, which were connected to a vacuum pump. In this work, the liquids were discharged from the tapholes located at $50 \mathrm{~mm}$ from the
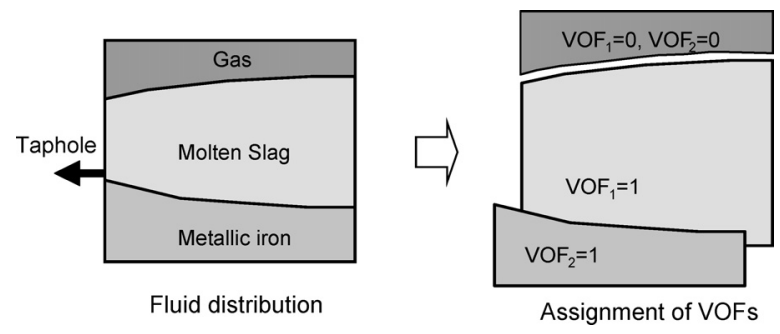

Fig. 1. Assignment of VOF variables for surfaces expression.

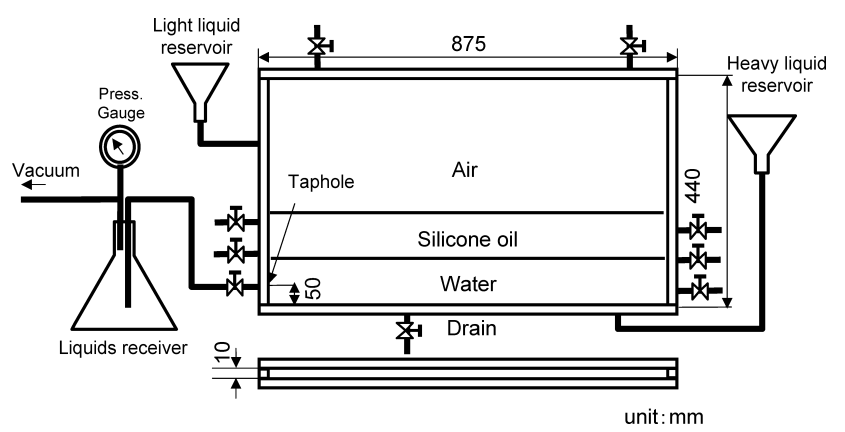

Fig. 2. Schematic drawing of experimental equipment for twodimensional model.

bottom. The valves located at the top of the vessel were opened during experiments. A combination of pure water and silicone oil was used to represent molten iron and slag, respectively. The kinematic viscosity and density of silicone oil were $1.0 \times 10^{-4} \mathrm{~m}^{2} / \mathrm{s}$ and $0.965 \times 10^{3} \mathrm{~kg} / \mathrm{m}^{3}$, respectively.

During the experiment, the behavior of air-silicone oil and silicone oil-water interfaces was filmed by a digital video camera. The interfaces shapes were traced on a computer. When air-silicone oil interface reached the taphole, the taphole was closed. The outlet velocity was calculated based on the volume of liquids removed over the time period.

\subsection{Experimental and Numerical Results}

For the validation of the two-dimensional mathematical model, experimental work and calculation were performed on various cases. Some results are shown in Fig. 3. As far as possible, the initial and boundary conditions for the calculations were exactly the same as those for the experimental conditions. In the two-dimensional mathematical model, the measured flow volume of silicone oil and water gave the outlet velocity. In Case a), the initial levels of water and silicone oil were $170 \mathrm{~mm}$ and $85 \mathrm{~mm}$, respectively. In Case b), the initial levels of water and silicone oil were $80 \mathrm{~mm}$ and $40 \mathrm{~mm}$, respectively. Since the densities of water and oil were so close in comparison to those of iron and slag, the shape of the profile is exaggerated for the experimental system.

In Case a), water initially flowed through the taphole. Following the arrival of the silicone oil-water interface at the taphole, both water and silicone oil flowed out together, with water having the higher proportion of the drained fluid. When the drainage of water was almost finished, the proportion of the oil drained increased.

As shown in Case b), even when the initial water-silicone oil interface is located below the taphole, the 

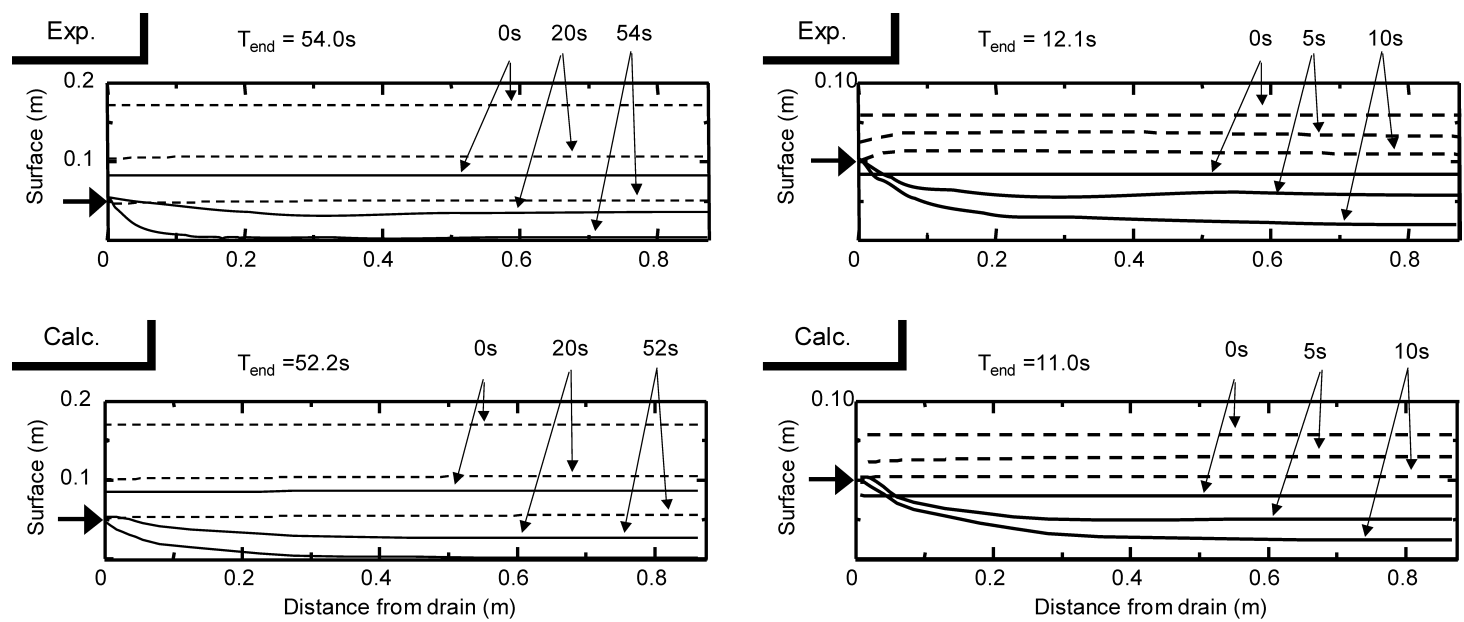

- -Air-Silicone oil interface — Silicone oil - Water interface

a) Air - Silicone oil - Water system (1)

- -Air-Silicone oil interface — Silicone oil - Water interface

b) Air - Silicone oil - Water system (2)

Fig. 3. Comparison of calculated and measured results of interfaces shapes.

water-silicone oil interface rises towards the taphole in the vicinity of the taphole. In this case, not only silicone oil but also water were drained from the taphole, as Tanzil et al. reported in their work. ${ }^{4}$ The two-dimensional mathematical model was able to reproduce this behavior. This model predicted the time when the water-silicone oil interface reached the taphole correctly within $2-4$ s error.

\section{Three-dimensional Modelling}

Since the accuracy of the two-dimensional mathematical model was confirmed in Sec. 2.4, the mathematical model was extended to a three-dimensional cylindrical coordinate system for an actual size of a blast furnace.

\subsection{Pressure Drop Evaluation Model in a Taphole}

When a taphole is assumed a pipe having $D(\mathrm{~m})$ in diameter, $L(\mathrm{~m})$ in taphole length, $e(\mathrm{~m})$ in surface roughness of the taphole as in Fig. 4, friction factor $f$ is derived from Eq. (4).

$$
f=\frac{0.0626}{\left[\log \left(\frac{e}{3.7 D}+\frac{5.74}{\operatorname{Re}^{0.9}}\right)\right]^{2}}
$$

Considering the force balance of shearing force at the wall of the taphole and pressure difference between the inlet and outlet of the taphole, total drainage rate of iron and slag $\bar{u}$ is derived from Eq. (5)

$$
\bar{u}=\sqrt{\frac{\Delta P D}{2 f \rho L}}
$$

Equations (4) and (5) contain taphole diameter $D$, taphole depth $L$, and surface roughness of the taphole $e$. If the flow resistance in the taphole is the dominant factor, the drainage rate is mainly determined by these three parameters, and the drainage rate should be a function of these parameters.

Figure 5 shows total, iron and slag drainage rates of

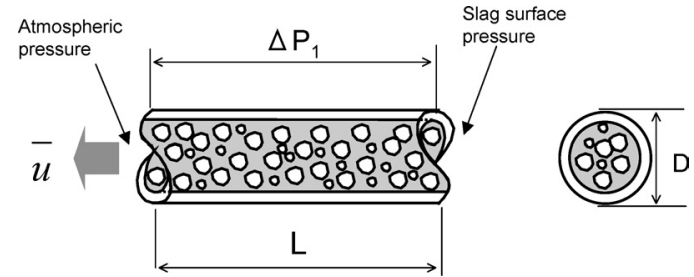

Fig. 4. Schematic diagram of pressure drop evaluation model in a taphole.

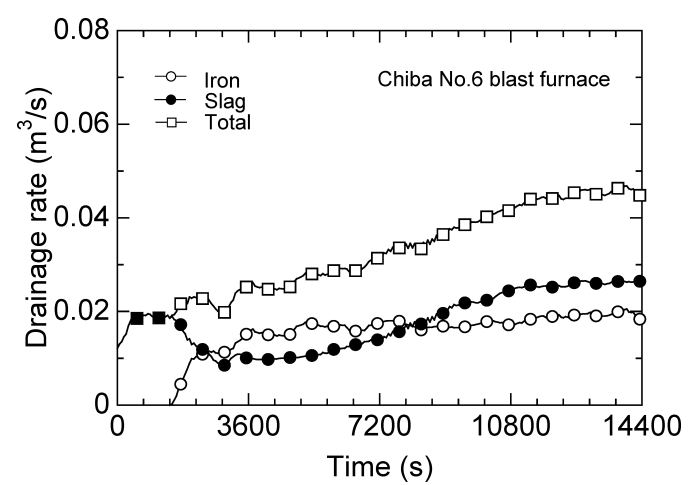

Fig. 5. Total, iron and slag drainage rate variations of Chiba No. 6 blast furnace during a tap.

Chiba No. 6 blast furnace. The initial total drainage rate is about $0.02 \mathrm{~m}^{3} / \mathrm{s}$, and the final total drainage rate is about $0.05 \mathrm{~m}^{3} / \mathrm{s}$. The taphole conditions suppose to dominate the total drainage rate, because the total drainage rate nearly increases linearly. In the early stage of the tap, slag drains prior to iron. The drainage rate of slag decreases once, and increases again. In contrast, the drainage rate of iron increases during the tap, however, the increasing speed of the drainage rate becomes slow. Except early stage of the tap, the volume fraction of iron in the taphole during the tap was about $0.4-0.6$. Therefore, apparent properties of the fluid required for the Eqs. (4) and (5) were given by mean properties of iron and slag.

The taphole diameter during the tap was measured with a video camera. The taphole diameter varied from 60 to 68 $\mathrm{mm}$ during the tap. Figure 6 shows estimated temporal 


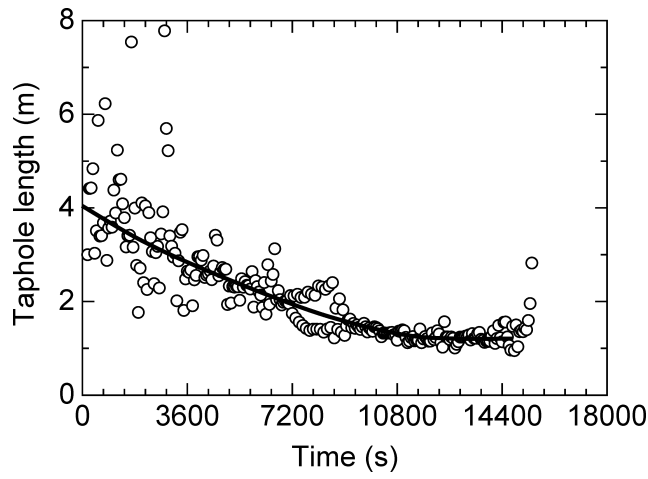

Fig. 6. Estimated temporal taphole length variation of Chiba No. 6 blast furnace during the tap by pressure drop evaluation model.

variation of the taphole length during the tap from Eqs. (4) and (5) by using temporal variation of the total drainage rate shown in Fig. 5 and that of the measured taphole diameter. Although, the estimated taphole lengths are scattered, at the beginning of the tap, the taphole length is about $4.0 \mathrm{~m}$ which coincide with an actual measurement. At the end of the tap, the taphole length is about $1.0 \mathrm{~m}$ which is slightly shorter than an expected length, however, the trend is suitable. Therefore, the taphole behavior can be described by this model.

The effect of each parameter on the drainage rate was investigated by fixing other parameters to certain representative values as shown in Figs. 7-9. The representative value of taphole diameter $D$ was $64 \mathrm{~mm}$, because the measured taphole diameter variation range during the tap was $60 \mathrm{~mm}$ to $68 \mathrm{~mm}$. The representative value of taphole length $L$ was $2.5 \mathrm{~m}$, and surface roughness of the taphole $e$ was $1 \mathrm{~mm}$. The inflow pressure of the taphole was fixed to $3.5 \times 10^{5} \mathrm{~Pa}$ which was determined from a blasting pressure into tuyeres; the outflow pressure was $1.0 \times 10^{5} \mathrm{~Pa}$ (atmospheric pressure).

Variation of the taphole diameter has a great effect on the drainage rate (Fig. 7). When the taphole diameter is $42 \mathrm{~mm}$, the drainage rate is $0.008 \mathrm{~m}^{3} / \mathrm{s}$. When the taphole diameter is $78 \mathrm{~mm}$, the drainage rate is $0.05 \mathrm{~m}^{3} / \mathrm{min}$. Thus, increase of the taphole diameter from 42 to $78 \mathrm{~mm}$ provides about five times drainage rate.

As decreasing the taphole length, the drainage rate increases gradually (Fig. 8). When the taphole length is about $1.0-2.0 \mathrm{~m}$, variation of the taphole length has a large effect on the drainage rate. Although, when the taphole length is more than $3.0 \mathrm{~m}$, variation of the taphole length has a small effect on the drainage rate.

The effect of surface roughness on the drainage rate is relatively smaller than that of the taphole diameter and the taphole length (Fig. 9). When the surface is smooth, the drainage rate is about $0.035 \mathrm{~m}^{3} / \mathrm{s}$. When the surface roughness is even $9 \mathrm{~mm}$, the drainage rate is about $0.018 \mathrm{~m}^{3} / \mathrm{s}$.

Considering the fact that the measured taphole diameter of Chiba No. 6 blast furnace during the tap is $60-68 \mathrm{~mm}$, and the drainage rate is about $0.017-0.05 \mathrm{~m}^{3} / \mathrm{s}$, it is impossible to describe the drainage rate variation by one of these parameters change. These parameters should change simultaneously. However, temporal variation of the taphole diameter has the greatest effect on the drainage rate variation.

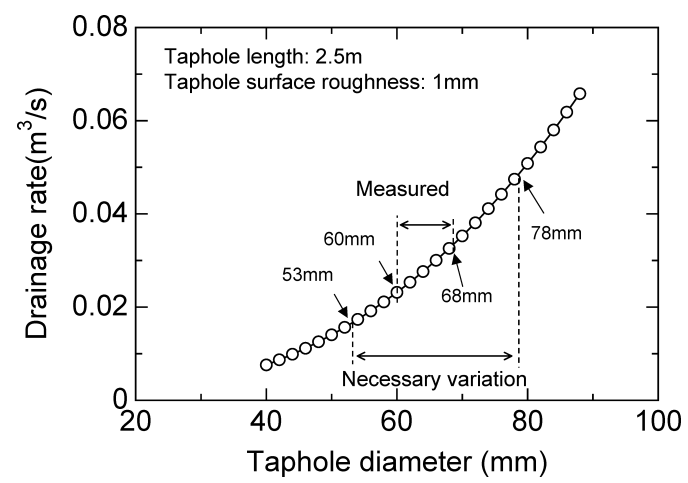

Fig. 7. Necessary taphole diameter variation range to describe the total drainage rate variation. Taphole length is $2.5 \mathrm{~m}$. Taphole surface roughness is $1 \mathrm{~mm}$.

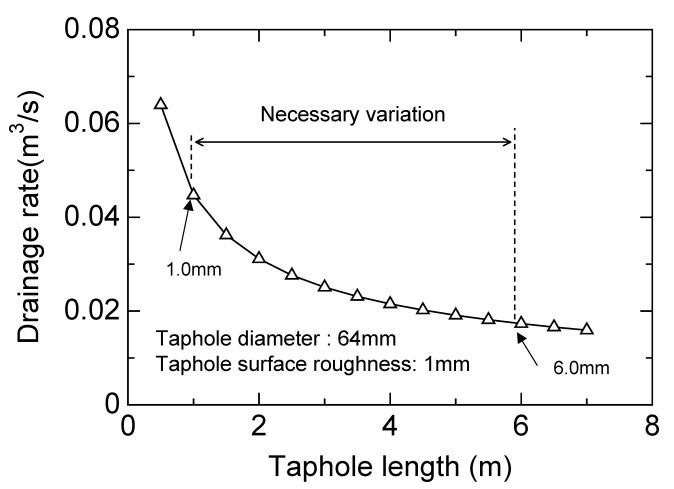

Fig. 8. Necessary taphole length variation range to describe the total drainage rate variation. Taphole diameter is $64 \mathrm{~mm}$. Taphole surface roughness is $1 \mathrm{~mm}$.

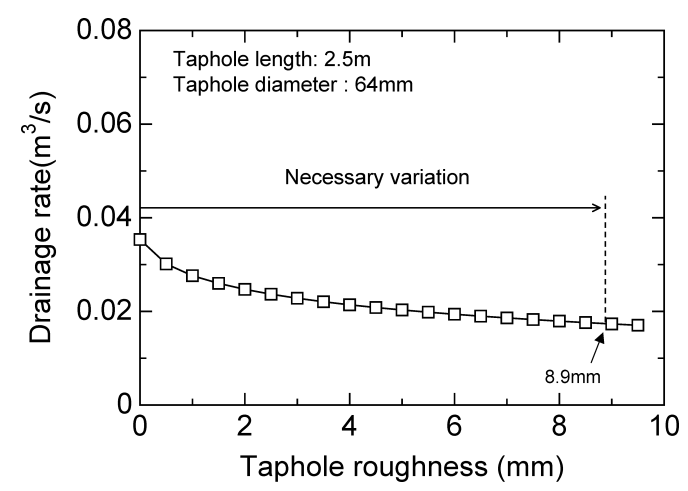

Fig. 9. Necessary taphole surface roughness variation range to describe the total drainage rate variation. Taphole length is $2.5 \mathrm{~m}$. Taphole diameter is $64 \mathrm{~mm}$.

Therefore, in later calculations, only the taphole diameter was varied as the drainage time, and $L$ and $e$ were fixed to $2.5 \mathrm{~m}$ and $1 \mathrm{~mm}$, respectively. Initial taphole diameter was $53 \mathrm{~mm}$, and expansion rate of the taphole was $1.736 \times 10^{-6} \mathrm{~m} / \mathrm{s}$ according to the actual performance of the Chiba No. 6 blast furnace. The outflow pressure was fixed to $1.0 \times 10^{5} \mathrm{~Pa}$; the inflow pressure was obtained from the fluids flow estimation model at each time.

\subsection{Fluids Flow Estimation Model in a Hearth}

The governing equations for fluids flow used in the threedimensional mathematical model are based on the HSMAC method, ${ }^{8)}$ are described by Eqs. (6)-(9). 


$$
\begin{array}{r}
\frac{1}{r} \frac{\partial}{\partial r}\left(r \varepsilon v_{r}\right)+\frac{1}{r} \frac{\partial \varepsilon v_{\theta}}{\partial \theta}+\frac{\partial \varepsilon v_{z}}{\partial z}=0 \ldots \ldots \ldots \ldots . .(6) \\
\frac{\partial \varepsilon \rho v_{r}}{\partial t}+v_{r} \frac{\partial \varepsilon \rho v_{r}}{\partial r}+\frac{v_{\theta}}{r} \frac{\partial \varepsilon \rho v_{r}}{\partial \theta}+v_{z} \frac{\partial \varepsilon \rho v_{r}}{\partial z}-v_{\theta} \frac{\varepsilon \rho v_{\theta}}{r} \\
=-\varepsilon \frac{\partial p}{\partial r}+\varepsilon \rho S_{v_{r}} \ldots \ldots \ldots \ldots \ldots \ldots \ldots \ldots . .(7) \\
\frac{\partial \varepsilon \rho v_{\theta}}{\partial t}+v_{r} \frac{\partial \varepsilon \rho v_{\theta}}{\partial r}+\frac{v_{\theta}}{r} \frac{\partial \varepsilon \rho v_{\theta}}{\partial \theta}+v_{z} \frac{\partial \varepsilon \rho v_{\theta}}{\partial z}+v_{r} \frac{\varepsilon \rho v_{\theta}}{r} \\
=-\varepsilon \frac{1}{r} \frac{\partial p}{\partial \theta}+\varepsilon \rho S_{v_{\theta}} \ldots \ldots \ldots \ldots \ldots \ldots \ldots . .(8) \\
\frac{\partial \varepsilon \rho v_{z}}{\partial t}+v_{r} \frac{\partial \varepsilon \rho v_{z}}{\partial r}+\frac{v_{\theta}}{r} \frac{\partial \varepsilon \rho v_{z}}{\partial \theta}+v_{z} \frac{\partial \varepsilon \rho v_{z}}{\partial z} \\
=-\varepsilon \frac{\partial p}{\partial z}+\varepsilon \rho S_{v_{z}}-\varepsilon \rho g \ldots \ldots \ldots \ldots \ldots \ldots \ldots . .(9)
\end{array}
$$

where, $v_{r}$ is radial velocity $(\mathrm{m} / \mathrm{s}), v_{z}$ is vertical velocity $(\mathrm{m} / \mathrm{s}), v_{\theta}$ is circumferential velocity $(\mathrm{m} / \mathrm{s}), r$ is radial axis $(\mathrm{m}), \theta$ is circumferential coordinate $(\mathrm{m}), z$ is vertical coordinate $(\mathrm{m}), \varepsilon$ is fluid fraction $(-)$ and $S$ is an interaction force between fluids and packed coke $\left(\mathrm{m} / \mathrm{s}^{2}\right)$.

The source term, $S$, was evaluated using the KozenyCarman's equation ${ }^{10)}$ shown in Eq. (10).

$$
\vec{S}=180 \frac{\mu}{\rho} \frac{(1-\varepsilon)^{2}}{d_{\mathrm{p}}^{2} \varepsilon^{2}} \vec{u}
$$

where, $\mu$ is the fluid viscosity $(\mathrm{Pa} \cdot \mathrm{s}), d_{\mathrm{p}}$ is particle diameter (m) and $\vec{u}$ is fluid velocity.

Equations (6)-(10) were solved for a single fluid, which had variable properties depending on the position in the packed bed. The VOF method was applied for the calculation of interfaces, as in the case of the two-dimensional mathematical model.

\subsection{Calculation Procedure}

In this model, molten iron and slag dropped on the iron and slag surface, respectively. Total drainage rate was calculated by Eq. (5) with the pressure difference between inflow pressure and outflow pressure for the taphole $\Delta P_{1}$, properties of fluids in the taphole determined by weighted average of the fluid existed in the nearest cell to the taphole. Fluid flow in the hearth was solved with the total drainage rate. Slag and iron surfaces moved according with the fluid flow. Inflow pressure for the taphole was obtained from the fluid flow. $\Delta P_{1}$ was recalculated by subtracting the outflow pressure from the inflow pressure for the taphole. Iron and slag drainage rates were calculated from their mass balances. These steps were repeated until the slag surface reaches the taphole. When the slag surface reached the taphole, the taphole was closed. If the fluids flow behavior and drainage rates pattern did not reach quasi-steady state, the other taphole was opened, and above procedure was repeated for the next tap. The total drainage rate was affected by the $\Delta P_{1}$, and $\Delta P_{1}$ was determined by the fluid flow in the hearth. By this procedure, the total drainage rate affected by the packed bed structure in the hearth was obtained.

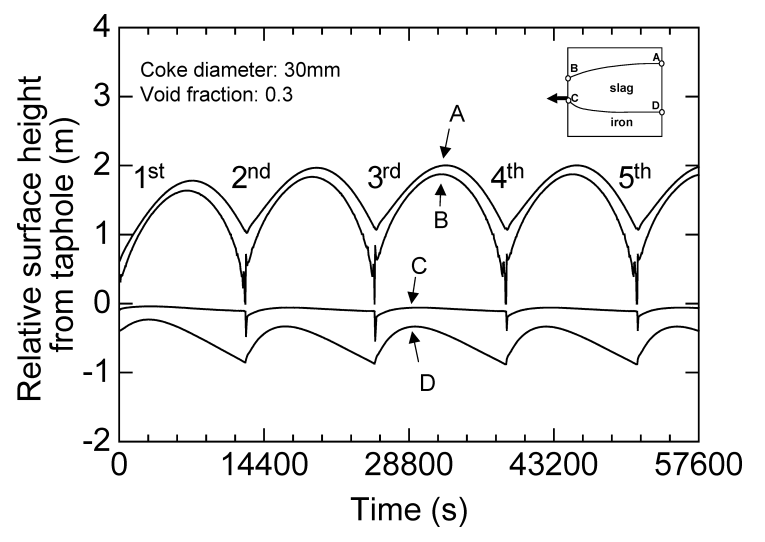

Fig. 10. Time evolution of relative slag surface and iron-slag interface height from the taphole.

\subsection{Conditions for Calculations}

Conditions of an assumed blast furnace are: Inner volume of the blast furnace is $5000 \mathrm{~m}^{3}$, the hearth diameter is $14 \mathrm{~m}$, distance between bottom of the hearth and the taphole is $3.0 \mathrm{~m}$, and quantity of production is 10000 tonnes $/ \mathrm{d}$. The void fraction is 0.30 . Temperature in the hearth is $1773 \mathrm{~K}$. Composition of the slag is 0.3 mass $\% \mathrm{FeO}, 34$ mass $\% \mathrm{SiO}_{2}, 15$ mass $\% \mathrm{Al}_{2} \mathrm{O}_{3}, 42$ mass $\% \mathrm{CaO}$ and 6.5 mass $\% \mathrm{MgO}$. Iron and slag properties were given by the function of their composition and temperature. ${ }^{11)}$ In this work, molten iron and slag dropped on the iron and slag surface uniformly, because the effect of iron and slag dropping pattern on the surfaces was relatively small. Interactive force between the molten iron and slag was not considered in this model. The iron and slag were tapped from two tapholes located opposite angle alternately until drainage behavior reached quasi-steady state. Number of grid cells were $15(r) \times 22(z) \times 32(\theta)$, and time increment was set small enough value to satisfy numerical stability.

\section{Results and Discussions}

\subsection{Validation of Three-dimensional Mathematical Model}

For the validation of the three-dimensional mathematical model, calculation was performed on the same conditions with Chiba No. 6 blast furnace. Figure 10 shows a temporal variation of the relative surfaces height. The slag surface exists between the line $\mathrm{A}$ and $\mathrm{B}$, and the iron-slag interface exists between the line $\mathrm{C}$ and $\mathrm{D}$. The drainage behavior reached quasi-steady state in the $3 \mathrm{rd}$ tap. The highest point of the slag surface (A) is about $2.0 \mathrm{~m}$ relative to the taphole level in the middle of the tap. The lowest point of the slag surface (B) reaches the taphole level at the end of the tap. The difference between the highest and lowest point of the slag surface shows maximum value at the end of the tap. The highest point of the iron-slag interface (C) moves upward against the gravity at the beginning of the tap, and stays at the tap hole level until the end of the tap. At the end of the tap, the iron-slag interfaces near the taphole falls bellow the taphole immediately due to the stoppage of the taphole. The lowest point of the iron-slag interface (D) moves upward at the beginning of the tap, and reaches the maximum level in about $3600 \mathrm{~s}$, and then moves downward 


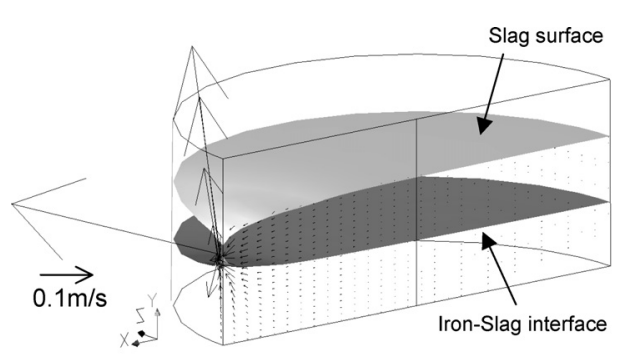

a) Top view

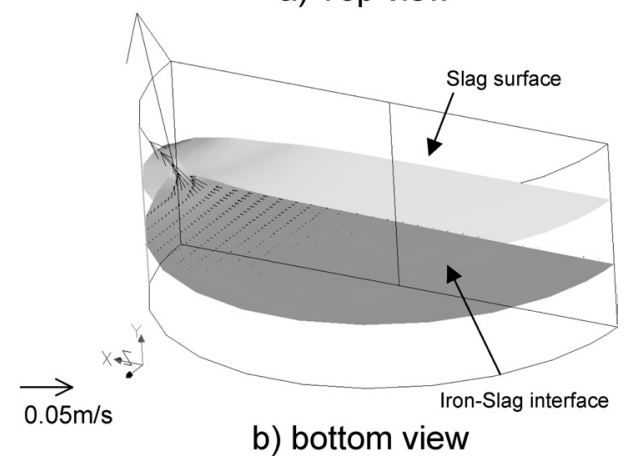

Fig. 11. Slag surfaces, iron-slag interfaces and velocity distributions in the hearth at the end of the tap. Coke diameter in the packed bed is $30 \mathrm{~mm}$.

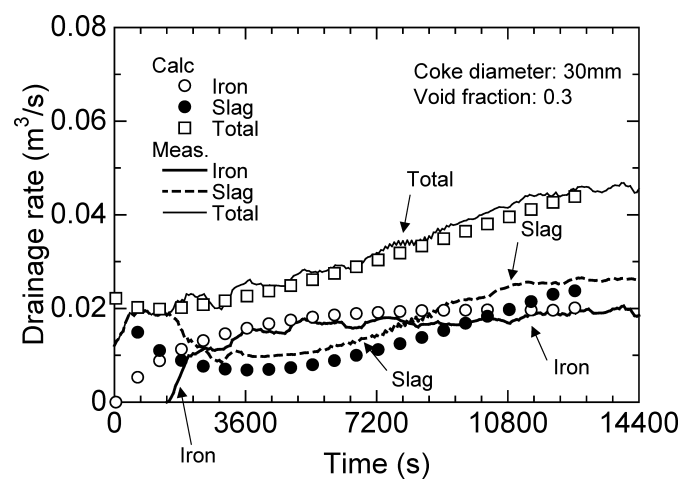

Fig. 12. Comparison of calculated iron, slag and total drainage rate of Chiba No. 6 blast furnace with the measured ones.

gradually. Finally, the lowest point of the iron-slag interface returns to the same level at the beginning of the tap.

Examples of slag surfaces, iron-slag interfaces and velocity distribution just before the end of a tap are shown in Fig. 11. The position and shape of the slag surface depends on the balance between the gravitational force and the resistance to slag flow through a packed coke bed. The slag surface has a sharp inclination near the taphole. The iron existed bellow the taphole can drain, because the iron-slag interface near the taphole is at the same level as the taphole, although the average iron level is lower than the taphole level. The iron just bellow the iron-slag interface near the taphole has extremely large velocity, because the volumetric drainage rate of iron is almost same as that of slag in spite of small cross sectional area of iron flow channel near the taphole due to the iron-slag interface shape.

A comparison of measured and calculated total, iron and slag drainage rate of Chiba No. 6 blast furnace is shown in Fig. 12. The calculated total drainage rate shows good agreement with the measured one. The calculated iron drainage rate increases gradually, and reaches the peak
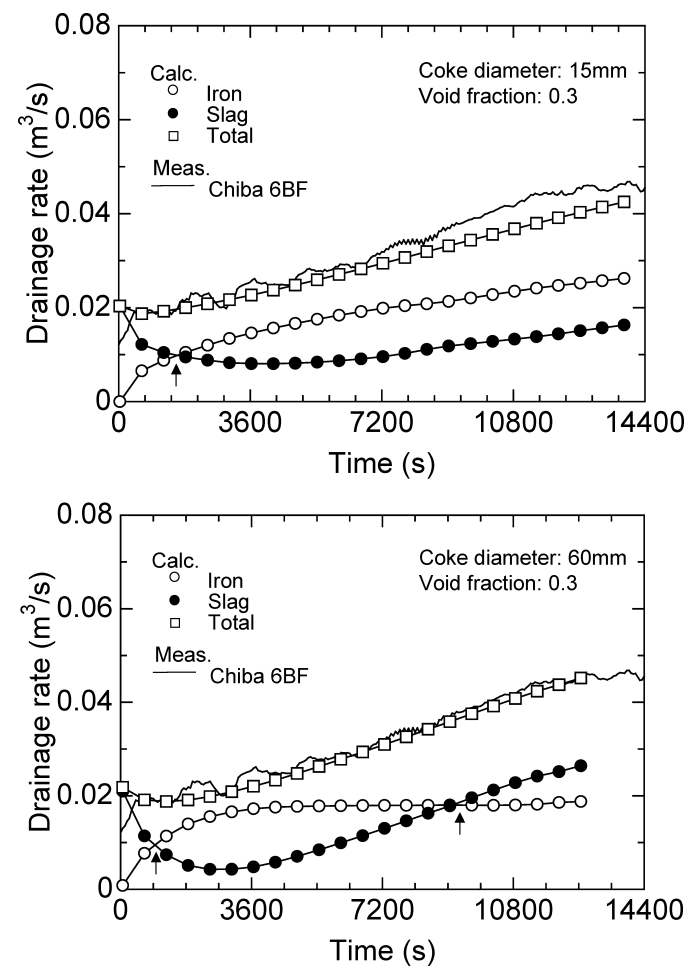

Fig. 13. Effect of packed coke diameter on temporal variation of iron, slag and total drainage rate. Coke packed bed is uniform.

value as in the case of the measured one. The calculated slag drainage rate decreases once, and reaches the bottom, and rises again as in the case of the measured one. The measured slag drainage rate is slightly larger than the calculated one through out the tap, because the slag ratio in the tap is slightly larger than the daily mean slag ratio. There is a small difference in the calculated and measured iron and slag drainage rate at the beginning of the tap, however, the calculated iron and slag drainage rate show almost the same behavior with the experimental one.

\subsection{Effect of Coke Diameter of the Packed Bed in the Hearth}

Figure 13 shows temporal variation of total, iron and slag drainage rate during the tap with $15 \mathrm{~mm}$ and $60 \mathrm{~mm}$ of coke for the packed bed, respectively. The coke diameter has a small effect on the total drainage rate. Thus, it is concluded that the taphole conditions dominate the total drainage rate under the terms of the assumed blast furnace conditions. Regarding the iron and slag drainage rate, as the coke diameter of packed bed increases, one or two intersections of the iron and slag drainage rate move toward the beginning of the cast. The reason is that as the coke diameter increases, the effect of the gravitational force relatively increases. Then, the iron and slag interface tends to keep in a horizontal position, as the result, iron flows prior to slag at the first half of the tap. In contrast, at the second half of the tap, slag drains more than iron to achieve their mass balances. Therefore, the packed bed structure in the hearth can be predicted from the iron and slag drainage rate patterns, if precise measurement of the drainage rate patterns can be achieved.

Figure 14 shows temporal variation of slag surface 

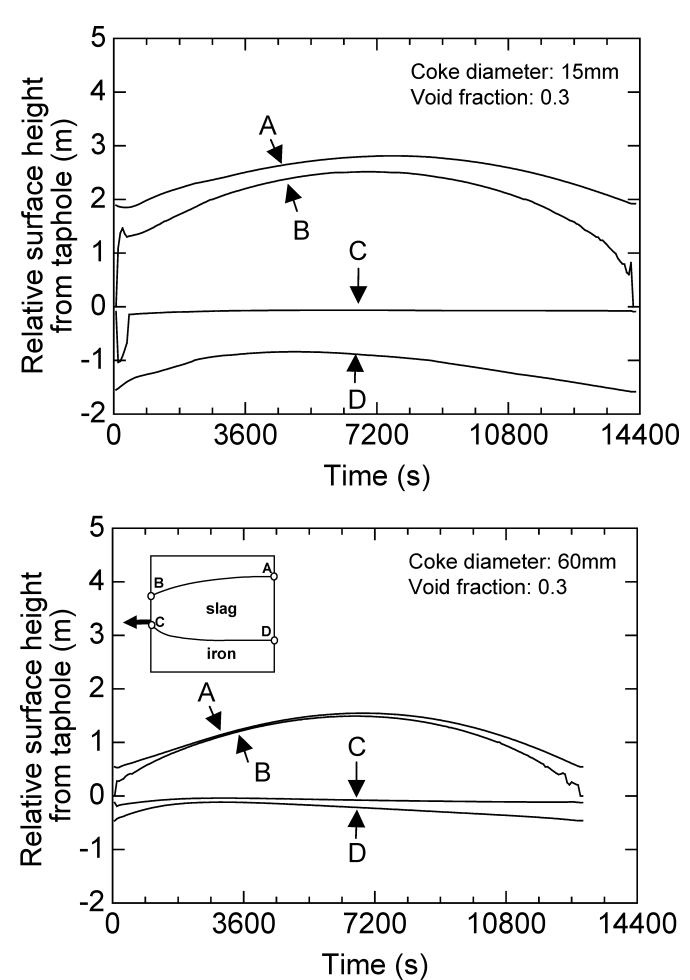

Fig. 14. Effect of packed coke diameter on slag surface and iron-slag interface height.

height and iron-slag interface height during the tap with $15 \mathrm{~mm}$ and $60 \mathrm{~mm}$ of coke, respectively. The coke diameter variation has a large effect on the surface and interface. When the coke diameter changes from $60 \mathrm{~mm}$ to $15 \mathrm{~mm}$, the highest and the lowest point of the slag surface (line A and $B$ in Fig. 14) move upward about $1.4 \mathrm{~m}$ and $1.0 \mathrm{~m}$ respectively in about $7200 \mathrm{~s}$. In contrast, the lowest point of iron-slag interface (D) moves downward about $1.0 \mathrm{~m}$ in about $7200 \mathrm{~s}$. Therefore, when the coke diameter changes from $60 \mathrm{~mm}$ to $15 \mathrm{~mm}$, the slag expands both upward and downward, and the maximum slag thickness increases about $2.4 \mathrm{~m}$.

The effect of packed coke diameter on iron and slag average thickness is shown in Fig. 15. As the coke diameter increases, the thickness of the slag layer decreases. In contrast, as the coke diameter increases, the thickness of the iron layer increases. That means it is impossible to reduce both the residual iron and slag volume at the same time. The decrease of the coke diameter causes decrease of the permeability in the packed bed, decrease of the inflow pressure for the taphole, and decrease of the drainage rate, as the result, increase of the drainage time.

Figure 16 shows the effect of packed coke diameter on terminal profiles of slag. As the coke diameter decreases which means decrease of permeability of the hearth, the thickness of the slag increases almost in proportion to the square of the coke diameter, and the slope of the slag surfaces and iron-slag interfaces toward the taphole becomes steeper, because the effect of the gravitational force becomes small relative to the pressure drop due to the fluids flow in the packed bed. As the results, when the permeability of the hearth is low, the iron considerably below the level of the taphole is able to drain during the tap as shown in Figs. 14 and 16.

To reduce the residual slag volume, it is effective to keep
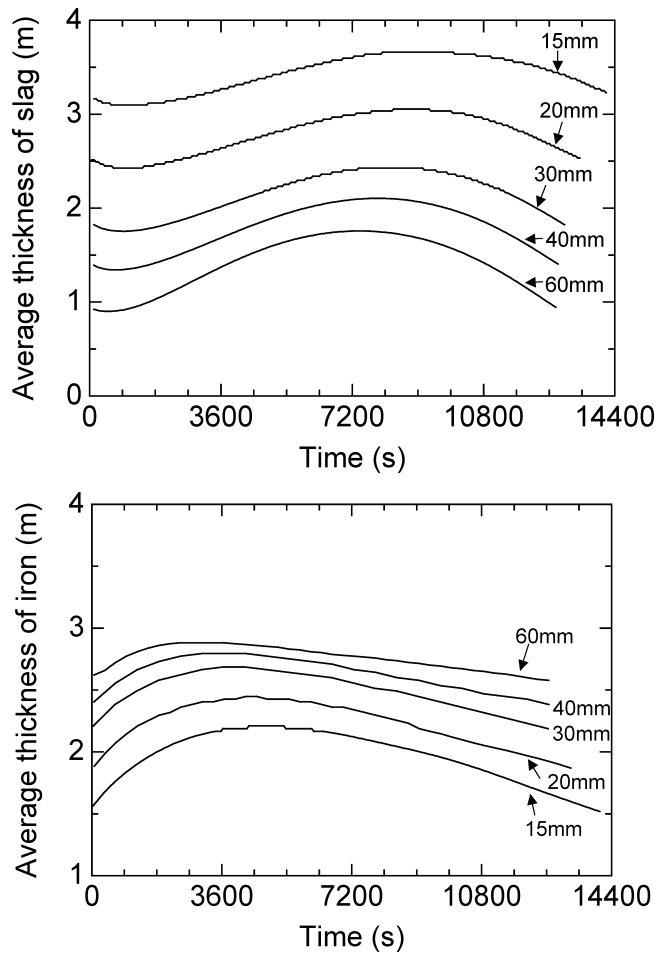

Fig. 15. Effect of packed coke diameter on average thickness of iron and slag.

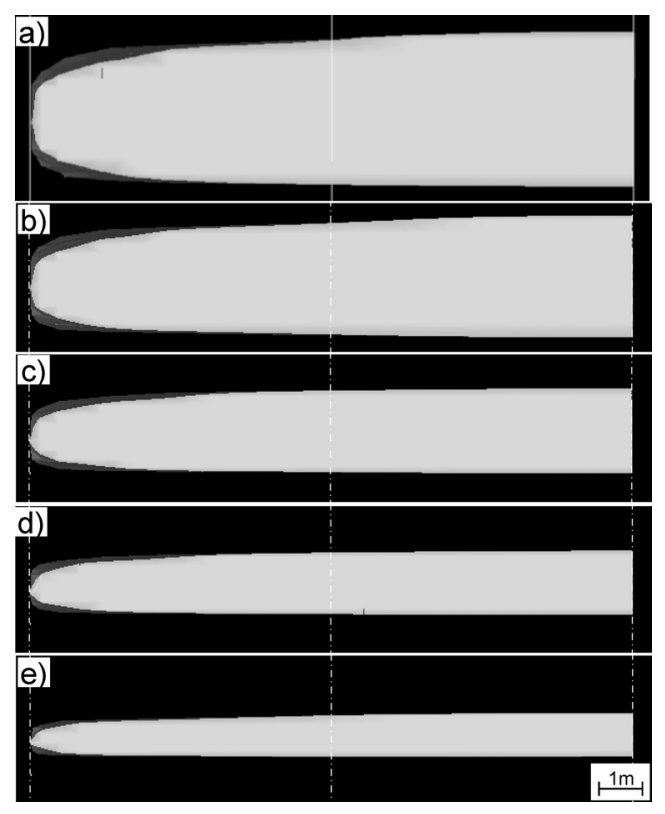

Fig. 16. Effect of packed coke diameter on terminal profiles of slag. a) Coke diameter is $15 \mathrm{~mm}$. b) Coke diameter is $20 \mathrm{~mm}$. c) Coke diameter is $30 \mathrm{~mm}$. d) Coke diameter is $40 \mathrm{~mm}$. e) Coke diameter is $60 \mathrm{~mm}$.

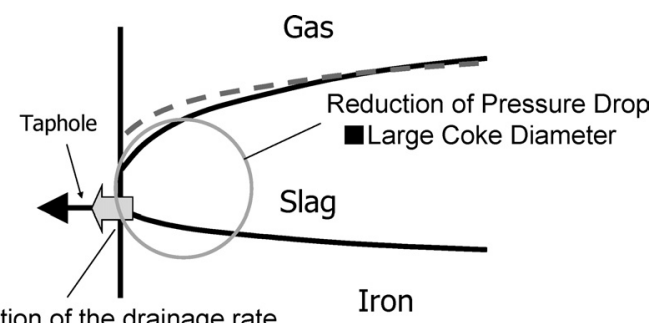

Reduction of the drainage rate

Iron at the end stage of the tap I

Fig. 17. Schematic view of iron and slag surfaces formation. 


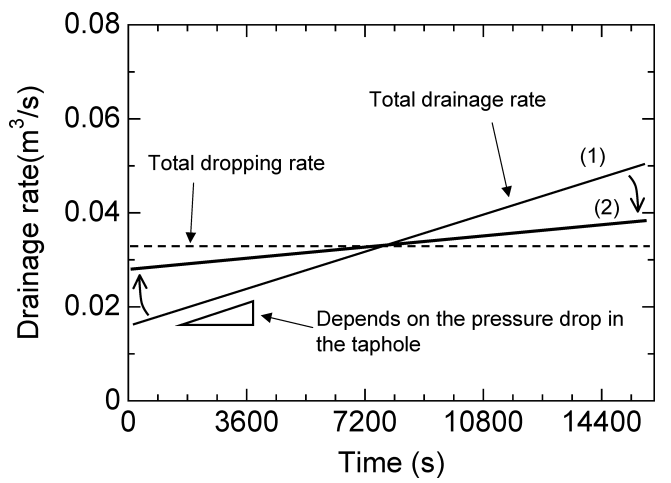

Fig. 18. Concept to reduce residual slag volume by way of taphole conditions.

high permeability around the taphole as shown in Fig. 17. However, in an actual blast furnace operation, it is very difficult to control the coke diameter in the hearth. Although, reduction of the drainage rate at the end of the tapping is also effective for the reduction of the residual slag volume.

For example, in Fig. 18, both line (1) and (2) achieve their mass balances. For the reduction of residual slag volume, the line (2) is better because the flow resistance at the end of the tap is relatively small. For the reduction of maximum slag level, line (2) is also better because the maximum slag levels is determined by the difference of the input and output. Considering the fact that the taphole conditions dominate the total drainage rate, it is concluded that it is important to reduce the ware rate of the mud during the tap. Therefore, in order to reduce residual slag volume, it is important to control taphole diameter change during tap.

\section{Conclusion}

Three-dimensional unsteady state mathematical model were developed based on the finite difference method to simulate molten slag and iron flow in a hearth of a blast furnace. The following results were obtained.

(1) Developed three-dimensional unsteady state mathematical model was validated with the measured total, iron and slag drainage rate of Chiba No. 6 blast furnace. The temporal variation of calculated total, iron and slag drainage rates showed almost the same behavior as the measured ones.

(2) The taphole conditions dominate the total drainage rate under the terms of the assumed blast furnace conditions $(15-60 \mathrm{~mm}$ in packed bed coke diameter, 0.30 in void fraction, $1773 \mathrm{~K}$ in the hearth temperature).

(3) In order to reduce residual slag volume, it is important to control taphole diameter change during tap.
Therefore, wear rate of mud has to be small to reduce residual slag volume in a hearth.

(4) When the permeability of the hearth is low, the iron considerably below the level of the taphole is able to drain during the tap.

(5) The decrease of the coke diameter causes increase of the residual slag volume, decrease of the residual iron volume. It is impossible to reduce the residual iron and slag volume at the same time.

\section{Acknowledgement}

The authors gratefully acknowledge JFE Corporation for supplying blast furnace geometrical and operational data.

\section{Nomenclature}

$d_{\mathrm{p}}$ : Particle diameter $(\mathrm{m})$

$g:$ Acceleration due to gravity $\left(\mathrm{m} / \mathrm{s}^{2}\right)$

$p: \quad$ pressure of fluids $(\mathrm{Pa})$

$r:$ Radial axis (m)

$S$ : Interaction force in 2D model, interaction force between fluids and packed coke in 3D model $\left(\mathrm{m} / \mathrm{s}^{2}\right)$

$t$ : Time (s)

$u$ : Horizontal velocity $(\mathrm{m} / \mathrm{s})$

$\vec{u}$ : Velocity of fluids $(\mathrm{m} / \mathrm{s})$

$v, v_{z}:$ Vertical velocity $(\mathrm{m} / \mathrm{s})$

$v_{r}:$ Radial velocity $(\mathrm{m} / \mathrm{s})$

$v_{\theta}:$ Circumferential velocity $(\mathrm{m} / \mathrm{s})$

$x, y, z$ : Coordinates (m)

Greek symbols

$\varepsilon: \quad$ Fluid fraction $(-)$

$\mu: \quad$ Viscosity $(\mathrm{Pa} \cdot \mathrm{s})$

$\theta$ : Circumferential axis (m)

$\rho: \quad$ Density $\left(\mathrm{kg} / \mathrm{m}^{3}\right)$

\section{REFERENCES}

1) T. Fukutake and K. Okabe: Tetsu-to-Hagané, 60 (1974), 607.

2) T. Fukutake and K. Okabe: Trans. Iron Steel Inst. Jpn., 16 (1976), 309.

3) T. Fukutake and K. Okabe: Trans. Iron Steel Inst. Jpn., 16 (1976), 317.

4) W. B. U. Tanzil, P. Zulli, J. M. Burgess and W. V. Pinczewski: Trans. Iron Steel Inst. Jpn., 24 (1984), 197.

5) P. Zulli, F. W. B. U. Tanzil, Q. He, B. D. Wright, I. Bean and R. J. Nightingale: The 4th Int. Cong. on Science and Technology of Ironmaking, Steel Institute VDEh, Düsseldorf, (2003), 482.

6) T. Nouchi, M. Yasui and K. Takeda: ISIJ Int., 43 (2003), 175.

7) J. Brännbacka and H. Saxén: ISIJ Int., 41 (2001), 1131.

8) C. W. Hirt, B. D. Nichols and N. C. Romero: Los Alamos Scientific Laboratory Report, LA-5852, (1975).

9) C. W. Hirt and B. D. Nichols: J. Comput. Phys., 39 (1981), 201.

10) P. C. Carman, Trans.: Inst. Chem. Eng., 15 (1937), 150.

11) T. Iida, H. Sakai, Y. Kita and K. Shigeno: ISIJ Int., 40 (2000), S110. 